\title{
患者さんと共創するプライマリ・ケア医療のための 発信力を期待して
}

\author{
前田 泉
}

本誌 33 巻 4 号 (2010 年 12 月号) の若林先生らの「内科医が一時撤退した地域における患者·住民の医師・ 医療に対する想いの検討」は，医療提供環境に関して患者側との情報の非対称性が明示され，個別の医療 者や医療機関レベルでは解決し得ない課題も提示しており非常に興味深く拝読いたしました. 単一施設で の研究のために一般化の制限が述べられていますが, 全国には調査対象となるようなエリアは多数存在し ていますので，学会主導で一般化できるエビデンス作りを支援するような活動を検討してはいかがでしょ う.

地域医療がギリギリのところで踏みとどまっている今こそ, 新生の日本プライマリ・ケア連合学会がエ ビデンスをもとに情報発信して, 患者さんの理解を得ながら地域医療を共創していかなければない時です。 社会の医療界への認識パターンは，エビデンスのない主張は，単なる自己の利益誘導ととられる傾向があ ります。そうならないためのコミュニケーション媒体の 1 つに本誌の役割をもつと広い視点で捉え, 本学 会のビジョンを実現する先駆的な研究を深めていく支援を編集者の機能としてもつことを検討してもよい のではないでしょうか.

小㟝先生らの「内科勤務医の仕事満足度, メンタルヘルス, 就労環境における男女差」も最近取り上げ られることの多い女性医師のライフステージの問題を,「女性医師のバーンアウト率の高さ」「仕事のコン トロール感の低さ」「収入を含めた就労条件の交渉スキル不足」なぼ，さらに踏み込んだ知見を提示してお ります。女性医師問題の根深さを考えさせられるとともに本エビデンスを広く医療界や社会へ働きかけて いかなければならない必要性も痛切に感じました。

最後に, 本学会が干支の「兔」のように軽快に跳ねていく若々しい活力により問題の提示から解決まで 行う学会に発展することを祈念しております。

前田 泉（まえたいずみ）

スナッジ・ラボ(株)

( ₹ 102-0093＼cjkstart東京都千代田区平河町 1-6-15 US ビル 8FＥ-mail:info@snudge-lab.com ) 